\title{
VD Vranov: Výzkum spodních výpustí a bezpečnostního přelivu
}

\section{JAN HLOM, PAVEL BALVÍN}

Klíčová slova: spodní výpust' - bezpečnostní přeliv - fyzikální modelování - matematické modelování

\section{SOUHRN}

Vodní dílo Vranov bylo dokončeno v roce 1934, kde byla na tehdejší dobu použita inovativní technologie koncových uzávěrů typu Johnson a válcové uzávěry. Za dobu jejich fungování nevyžadovaly větší opravy, probíhala pouze běžná údržba a drobné opravy. Nicméně, současný stav uzávěrů již nezaručuje z hlediska korozního a provozního poškození dlouhodobý spolehlivý provoz. Povodí Moravy, s. p., si nechalo vypracovat studii rekonstrukce regulačních uzávěrů, výsledkem této studie byl návrh výměny čtyř stávajících uzávěrư za čtyřri nové segmentové uzávěry. Cílem výzkumu bylo ověření funkčnosti nově navržených segmentových koncových regulačních uzávěrů spodních výpustí VD Vranov a dále jejich součinnost s korunovým bezpečnostním prèlivem a navazující kaskádou. V rámci výzkumu byly postaveny dva fyzikální modely - model jedné spodní výpusti ( $v$ měřitku $1: 14,68$ ) a model hrázového tělesa ( $v$ měřítku $1: 55$ ). $V$ rámci výzkumu na fyzikálním modelu spodní výpusti bylo cílem zejména stanovení kapacity spodní výpusti ve vztahu k hladině vody v nádrži, míre zatopení dolní vodou ve vývaru a stupni otevření segmentového uzávěru. Model hrázového tělesa sloužil pro posouzení prostorového proudění ve vývaru při převádění vody pres prelivná pole, respektive při součinnosti proudů od spodních výpustí a přelivných polí. Dále byla na modelu hrázového tělesa ověřována konzumční křivka bezpečnostního prèlivu. Naměřená konzumční křivka na fyzikálním modelu byla následně porovnána s konzumční křivkou získanou z výsekového matematického modelu. Matematický model byl sestaven a vypočítán v programu FLOW-3D.

\section{ÚVOD}

Vodní dílo Vranov je tvořeno přehradní hrází ležící nad obcí Vranov nad Dyjí a nádrží sahající při maximální hladině až $30 \mathrm{~km}$ proti proudu řeky Dyje s celkovým objemem 132,7 mil. m³, zatopená plocha nádrže činí 7,6 km². Vodní dílo (dále VD) bylo vybudováno v letech 1930 až 1934 v ř. km 175,405 a je součástí dyjské vodohospodářské soustavy. Vodní dílo Vranov je víceúčelová nádrž, mezi hlavní účely VD patří zejména akumulace vody pro zajištění minimálního průtoku a nadlepšení pro odběry, ochrana před velkými vodami a další využití jako napr. rekreace, rybolov apod. [1].

\section{Hráz vodního díla}

Vzdouvací objekt je tvořen tížnou betonovou hrází z litého betonu skládající se z 19 bloků o šírce 13,5 až 15 m a elektrárenského dvojbloku o šiřce 27 m. Délka hráze v koruně je 290,5 m, šiřka vozovky na koruně hráze je 4,5 m o kótě 353,39 m n. m., výška hráze od základu činí téměř 60 m.

\section{Bezpečnostní přeliv}

Bezpečnostní přeliv pro převádění povodní je vybudován jako korunový s přepadem vody přes betonovou hráz. Přeliv je složen z devíti nehrazených polí o světlé šířce 9 ×13,6 m s pevnými prahy na kótě 350,10 m n. m. Tři přepadová pole mezi elektrárenským dvojblokem a dvojblokem spodních výpustí tlumí přepadající vodu prímo ve vývaru. Pět z šesti polí príléhajících k levému břehu svádí přepadající vodu přes kaskádu v levém břehu do vývaru. Šesté přepadové pole tlumí přepadající vodu prímo ve vývaru.

\section{Vývar}

Vývar je nepravidelného tvaru o průměrné délce 58 m, šírce ve dně 40 m a s hloubkou pod prahem vývaru $4 \mathrm{~m}$. Na dně vývaru jsou umístěny dva mohutné rozrážeče o výšce 4,5 m, které slouží k tlumení energie výtokových paprsků z potrubí spodních výpustí. Betonový práh na konci vývaru je zakončen kamenným záhozem.

\section{Spodní výpusti}

Spodní výpusti (dále SV) jsou umístěny v levé části hráze a skládají se ze čtyř potrubí DN 1600 s osou na kótě 307,45 m n. m. V době svého dokončení byly tyto výpusti osazeny koncovými uzávěry na svou dobu s inovativní technologií, dva koncové uzávěry jsou typu Johnson a dva jsou válcové. Před koncovými uzávěry jsou osazeny revizními uzávěry - šoupaty a na návodní straně jsou spodní výpusti hrazeny revizním spustným stavidlovým uzávěrem typu Stoney.

\section{Vodní elektrárna a MVE}

Vodní elektrárna je situována v pravé části hráze, ve strojovně elektrárny jsou instalovány tři Francisovy turbíny, každá o maximální hltnosti $15 \mathrm{~m}^{3} / \mathrm{s}$. Malá vodní elektrárna je situována ve vývaru bezpečnostního přelivu vedle budovy vodní elektrárny, elektřinu generuje Francisova turbína o hltnosti $2,4 \mathrm{~m} 3 / \mathrm{s} \mathrm{slou-}$ žící pro prevádění minimálního zůstatkového průtoku.

\section{ZKOUMANÁ PROBLEMATIKA}

Hlavní motivací pro rekonstrukci koncových regulačních uzávěrů spodních výpustí je zejména jejich současný nevyhovující technický stav. Za dobu jejich 
fungování nevyžadovaly větší opravy, probíhala pouze běžná údržba a drobné opravy. Nicméně, současný stav tohoto zařizení jak z hlediska korozního, tak provozního poškození nezaručuje dlouhodobý spolehlivý provoz. Cílem plánované rekonstrukce je dosažení obnovení plné provozní spolehlivosti, včetně těsnosti na úrovni hodnot průsaků splňující současné normové požadavky a prodloužení životnosti k zajištění dlouhodobé bezpečnosti celého VD [2].

V prvním kroku Povodí Moravy, s. p., zadalo studii rekonstrukce regulačních uzávěrů firmě Aquatis, závěrem studie [2] bylo doporučení vyměnit všechny koncové uzávěry za čtyři nové segmentové uzávěry.

Dále bylo zpracováno „Posouzení hydraulických poměrů v prostoru spodních výpustí a navazujícího vývaru VD Vranov - rekonstrukce výpustí" [3], $\checkmark$ rámci této práce byly výpočtově ověřeny předpokládané kapacity spodních výpustí, proudové poměry ve vývaru a posouzeno nebezpečí kavitace segmentových uzávěrů. $V$ závěru byly doporučeny zkoušky, které by bylo vhodné provést na fyzikálních modelech VD Vranov.

Navazující fyzikální výzkum byl především zaměřen na:

- stanovení kapacity spodních výpustí ve vztahu k hladině vody v nádrži, míre zatopení dolní vodou ve vývaru a stupni otevření segmentového uzávěru,

— návrh konfuzorové části segmentového uzávěru pro optimalizaci kapacity SV a proudových poměrů ve SV a v navazujícím vývaru,

- stanovení podmínek pro minimalizaci kavitace při manipulaci se segmentovými uzávěry,

- prostorové proudění ve vývaru při samotném převádění vody přes přelivná pole, resp. príi součinnosti proudů od spodních výpustí a přelivných polí pro nový návrhový stav, tj. pro osazené segmentové uzávěry vč. stavební úpravy strojovny uzávěrů SV,

— bezpečné převádění povodňových průtoků přes VD s novými koncovými uzávěry spodních výpustí.

\section{FYZIKÁLNÍ MODELY}

V rámci laboratorního fyzikálního výzkumu byly postaveny dva modely - výsekový model jedné spodní výpusti v měřítku 1: 14,68 a model hrázového tělesa v měŕitku 1:55.

\section{Výsekový model spodní výpusti}

Výsekový model jedné spodní výpusti zahrnoval kompletní potrubí jedné výpusti s prostorem nátoku v nádrži, nátokovým kusem, otevřeným šoupětem, přechodovým kusem s pohyblivým segmentovým uzávěrem umístěným na konci strojovny uzávěrů a kompletním vývarem zakončeným na prahu vývaru (viz obr. 1). Jednotlivé komponenty modelu jako např. segmentový uzávěr s přechodovým kusem byly vytvořeny metodou 3D tisku. Voda byla na model přivedena přes Thomsonův přeliv, který zajištoval měření malých průtoků, velké průtoky byly měřeny príložným ultrazvukovým průtokoměrem na potrubí spodní výpusti. Limitním rozměrem mezních podmínek modelování podle Froudova zákona mechanické podobnosti byla výška výtokového otvoru segmentového uzávěru, která by neměla být menší než $60 \mathrm{~mm}$. V měřítku 1 : 15 je výška otvoru 64 mm, toto měřítko bylo označeno jako limitní. Výsledné měřítko 1: 14,68 bylo odvozeno podle skutečného průměru PE DN110 potrubí, které bylo použito na fyzikálním modelu. Fyzikální model měl půdorysné rozměry cca $3 \times 10 \mathrm{~m}$ a výšku 3,5 m.

Extrapolaci výsledků z modelu do skutečnosti ztěžoval fakt, že potrubí použité na fyzikálním modelu - PE DN110 Ize označit jako hydraulicky hladké, tj. proudění na modelu se nenacházelo v kvadratické oblasti odporů. V rámci daného měřitka a možnostech hydraulické laboratoře nebylo možné dosáhnout přesné podobnosti ztrát třením, proto bylo přistoupeno k jedinému možnému řešení, které doporučuji Gabriel a Čábelka [4] - byly určeny čtyři návrhové průtoky, pro které byly vypočítány hodnoty $\lambda$ ve skutečnosti (průtoky odpovídající otevření SV na 100, 75, 50 a $25 \%$ ). Proudění se pro tato otevření ve skutečnosti realizuje $\checkmark$ kvadratické oblasti odporů, hodnota součinitele tření $\lambda$ je cca 0,0138. Hodnota součinitele $\lambda$ byla proložena vodorovnou prímkou v Moodyho diagramu, místo průsečíků vodorovné prímky s křivkou pro hladké potrubí odpovídá hodnotě Reynoldsova čísla, pro které jsou ztráty třením v podobnosti, tato hodnota odpovídala otevření cca $75 \%$. Pro větší otevření byly ztráty třením na modelu mírně menší než ve skutečnosti, pro menší otevření byly ztráty mírně větší (relativní rozdíly ztrát byly v rozsahu cca $\pm 0,5 \%$ ). Pro tyto případy byla v extrapolaci výsledků fyzikálního modelu zavedena př́islušná korekce celkového spádu [5].
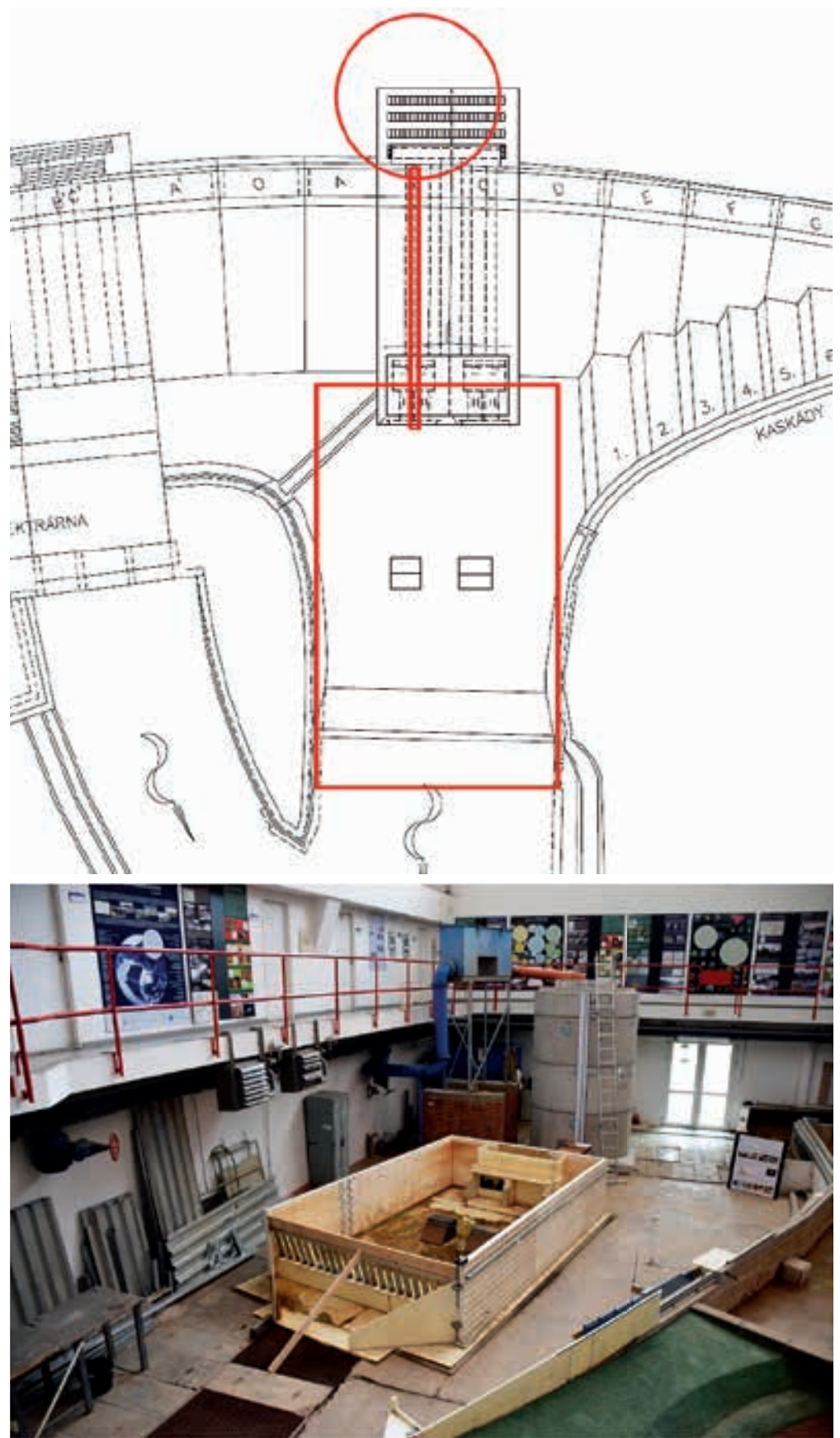

Obr. 1. Rozsah modelu spodní výpusti a fotografie vlastního provedení modelu spodní výpusti

Fig. 1. Bottom outlet physical model range and actual design 


\section{Model hrázového tělesa}

Model hrázového tělesa zahrnoval nádrž, těleso hráze s devíti poli bezpečnostního přelivu, kompletní kaskádu, vývar, VE, uzavíratelné potrubí spodních výpustí a navazující koryto pod VD Vranov v délce cca $200 \mathrm{~m}$ - viz obr. 2. Model byl postaven $\vee$ měrítku $1: 55$, limitním rozměrem byla výška přepadového paprsku proudnicově zaobleného přelivu, která by měla být větší než $50 \mathrm{~mm}$. Voda na model byla dávkována pomocí Thomsonova měrného přelivu z rozvodného systému laboratoře.

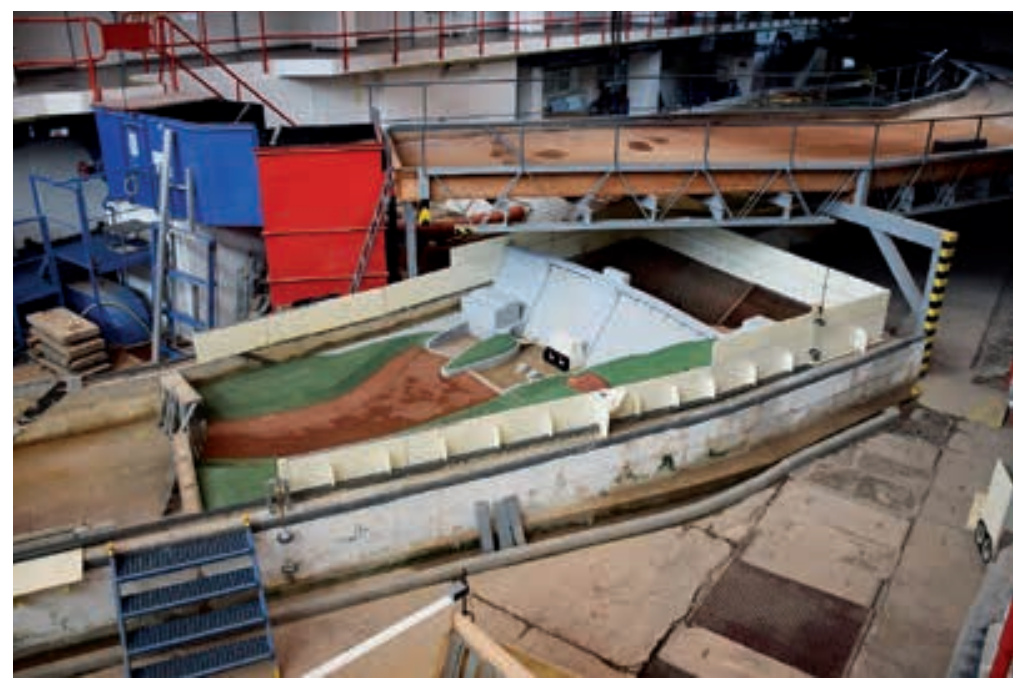

Obr. 2. Model hrázového tělesa

Fig. 2. Dam model

\section{FYZIKÁLNÍ VÝZKUM}

\section{Výzkum na modelu spodní výpusti}

V první fázi se výzkum orientoval na návrh přechodové části segmentového uzávěru (přechod z kruhového průřezu potrubí na obdélníkový výtokový profil). Přechodový kus a segmentový uzávěr byly navrženy podle podkladu "ČKD Blansko - Segmentové uzávěry", délka přechodového kusu je 2,7 m, přechodový kus se po obou stranách symetricky rozšiřuje pod úhlem $3,4^{\circ}$ a vertikálně je horní část konfuzoru zešikmena pod úhlem 13,2² průměr vstupního potrubí je 1,6 m, výtokový otvor je obdélníkový o šírce 1,92 m a výšce 0,96 m se zaoblenými rohy o poloměru 0,16 m. Výtoková plocha je o cca $9 \%$ menší než vstupní kruhový profil potrubí - toto opatření je provedeno z důvodu omezení nízkých tlaků v potrubí spodní výpusti. Takto navržený přechodový kus se v rámci fyzikálního testování osvědčil a byl schválen zástupci Povodí Moravy, s. p.

$\checkmark$ rámci pokusů byly posuzovány proudové poměry $v$ potrubí spodních výpustí a ve vývaru, tvar výtokového paprsku, tlumení kinetické energie výtokového paprsku a kapacita potrubí spodní výpusti. Měření bylo prováděno pro otevření segmentového uzávěru 12,5 až 100 \%, od minimální hladiny stálého nadržení až po mezní bezpečnou hladinu v nádrži a od minimální hladiny ve vývaru po hladinu odpovídající hladině dolní vody při povodni $Q_{10000}$. Celkem bylo realizováno 138 rozdílných stavů.

V rámci realizovaných pokusů nebylo pozorováno nestandardní chování výtokového paprsku, při všech stavech byl výtokový paprsek kompaktní a byl tlumen v prostoru vývaru pomocí stávajících rozrážečů. Pouze při otevření 70 \% a menších otevření segmentového uzávěru byl paprsek skloněn směrem dolů a narážel do plánovaného schodu konstrukce pro provizorní hrazení, v závěru výzkumné

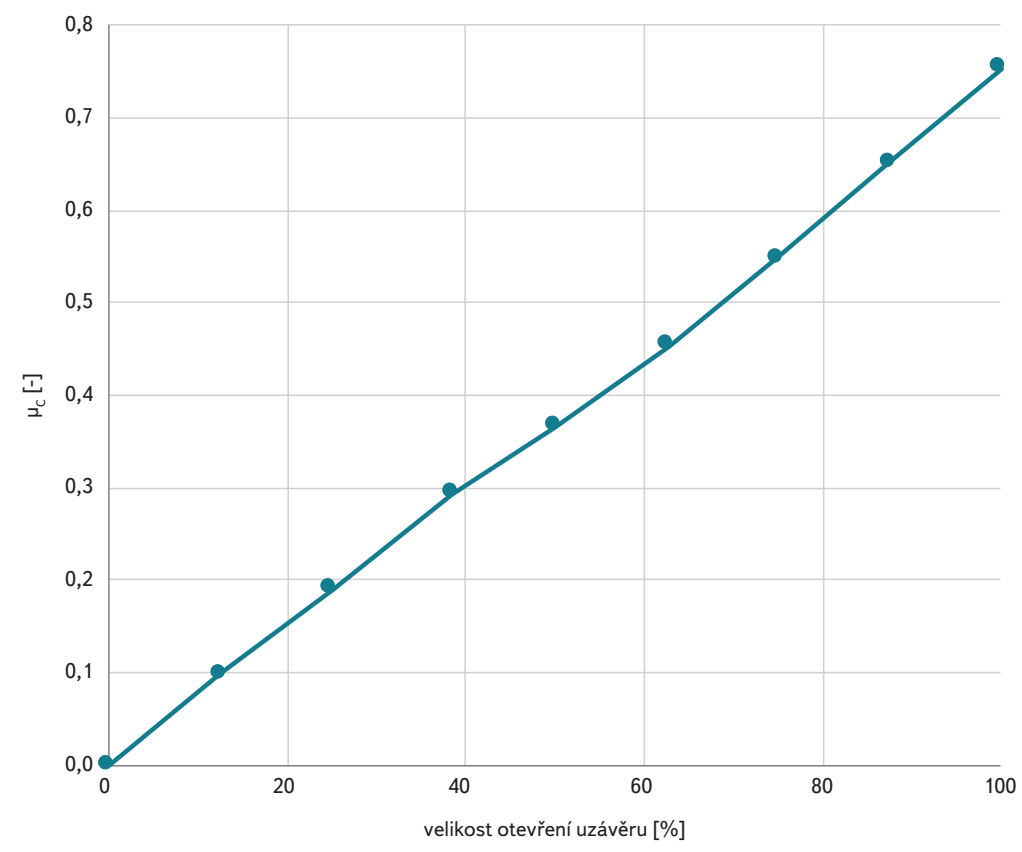

Obr. 3. Závislost výtokového součinitele $\mu$ na velikosti otevření uzávěru Fig. 3. Dependence of the flow outlet coefficient $\mu_{c}$ on the size of the radial gate opening

zprávy bylo doporučeno tento schod zešikmit a snížit tak, aby nebyl př́liš hydrodynamicky namáhán (výtokový paprsek dosahoval rychlosti až $26 \mathrm{~m} / \mathrm{s}$ ).

Z naměřených dat byla vyhodnocena kapacita potrubí spodní výpusti a získána závislost mezi \% otevření segmentového uzávěru a celkovým výtokovým součinitelem spodní výpusti $\mu_{c^{\prime}}$ ve kterém jsou zahrnuty veškeré ztráty na výpusti - viz obr. 3 (ztráta na nátoku, tření, ztráta na otevřeném šoupěti, ztráta na přechodovém kusu a ztráta na výtoku ze segmentového uzávěru). Pomocí znalosti tohoto vztahu Ize lehce zjistit výpočtem pomocí rovnice (1) (rovnice pro výtok otvorem) průtok spodní výpusti $Q$ na základě znalosti celkového spádu $H$ (rozdíl hladiny v nádrži a dolní vody ve vývaru, respektive osy potrubí, pokud je dolní voda níže), procentu otevření uzávěru (respektive výtokové ploše $S_{p}$ ) a gravitačnímu zrychlení g:

$$
Q=\mu_{c} \cdot S_{p} \cdot \sqrt{2 \cdot g \cdot H} \mathrm{~m}^{3} / \mathrm{s}
$$

kde $g$ je gravitační zrychlení $\left[\mathrm{m} / \mathrm{s}^{2}\right]$,

H spád $[\mathrm{m}]$,

Q průtok $\left[\mathrm{m}^{3} / \mathrm{s}\right]$

$S$ plocha $\left[\mathrm{m}^{2}\right]$,

$\mu \quad$ součinitel prepadu [-],

c celkový,

p potrubí.

\section{Výzkum na modelu hrázového tělesa}

Výzkum na modelu hrázového tělesa byl orientován na ověrení kapacity nehrazeného bezpečnostního přelivu, proudění v navazující kaskádě a prostorovém proudění ve vývaru. $\vee$ rámci pokusů byla testována předsazená konstrukce pro provizorní hrazení koncových segmentových uzávěrů umístěná před strojovnou spodních výpustí a zed' odklánějící proud z kaskády směřující na dělící ostrov mezi vodní elektrárnou a strojovnou spodních výpustí. 


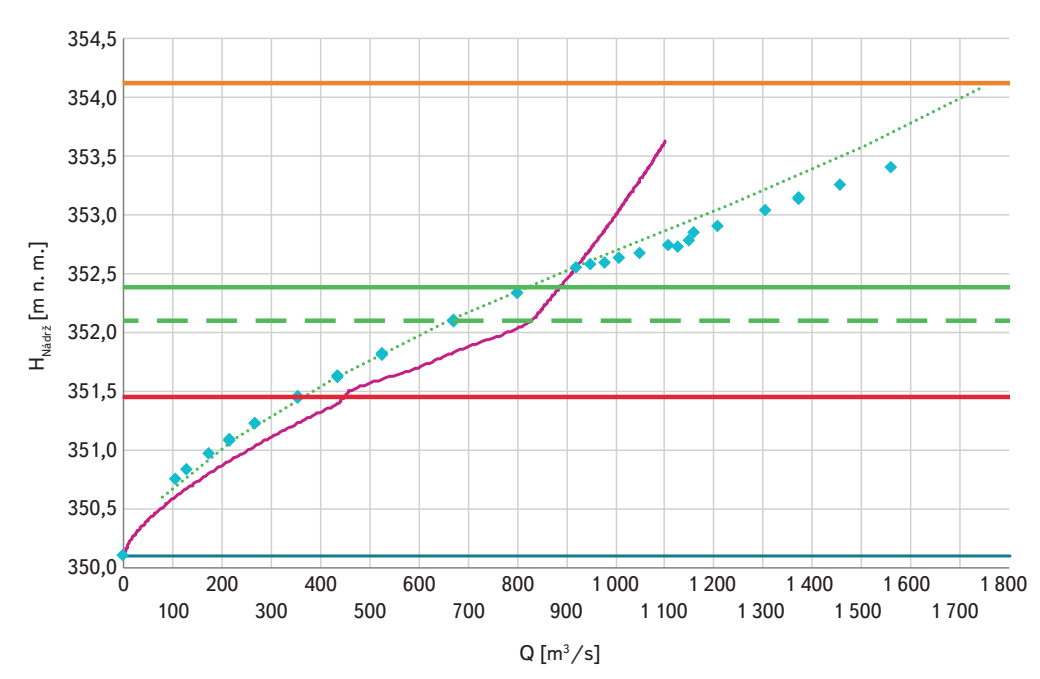

$\begin{array}{llll}\text { MBH } & \mathrm{H} \max & - \text { manipulační rád } & \text { * fyzikální model } \\ \text { mostovka po rekonstrukci } & - \text { hrana přelivu } & -- \text { mostovka původní } & \text { …. FLOW 3D }\end{array}$

Obr. 4. Konzumční křivka bezpečnostního prelivu

Fig. 4. Spillway discharge curve

Prostorové proudění v kaskádě a v navazujícím vývaru bylo posuzováno pro průtoky $Q_{1}-Q_{10000}(1374$ m³/s). V současném stavu představuje nebezpečí zejména proud z kaskády, který mírí kolmo na dělící ostrov mezi vodní elektrárnou a strojovnou spodních výpustí, ostrov je nejvíce ohrožen při průtoku odpovídajícímu $c c a Q_{50^{\prime}}$ kdy dolní voda není př́liš vysoko a proud z kaskády má již poměrně velkou kinetickou energii. Toto nebezpečí lze odstranit vhodnou kombinací provozu spodních výpustí, které odkloní proud z kaskády směrem do vývaru mimo dělící ostrov. Druhou variantou řešení je navrhovaná zed’, která je umístěna v prostoru před strojovnou dolních výpustí a proud z kaskády odklání směrem do vývaru bez nutnosti otevírat spodní výpusti.

Další problém nastává od průtoku $Q_{100}(435$ m³/s), při tomto průtoku je voda přepadající ze tři polí bezpečnostního přelivu, umístěných mezi vodní elektrárnou a strojovnou spodních výpustí, tlumena $v$ prostoru vývaru, který je v cca polovině ukončen dělícím ostrovem mezi vývarem a výtokem z vodní elektrárny. Při průtoku $Q_{100}$ začíná voda narážet na dělící ostrov a vzniká zde „výron" vody směrem na travnatou část ostrova, voda zde dosahuje rychlosti až $3 \mathrm{~m} / \mathrm{s}$. Řešení tohoto problému je možné pouze radikálním zmenšením dělícího ostrova.

Pro návrhový průtok $Q_{1000}$ byly změřeny výšky přelévání vody z kaskády odvádějící vodu z krajních polí bezpečnostního přelivu pro její případné navýšení na návrhový průtok.

Dalším cílem fyzikálního výzkumu bylo ověření konzumční křivky nehrazeného bezpečnostního přelivu. $V$ rámci výzkumu byly měřeny stavy od malých povodňových průtoků až po kontrolní povodeň $\mathrm{Q}_{10000}$. Problém při měření nastal $\checkmark$ okamžiku, kdy se hladina v nádrži ocitla na úrovni spodní hrany mostovky, $\checkmark$ tomto momentě došlo na přilnutí přepadového paprsku na spodní stranu mostovky a vzniku podtlaků, které způsobily zkreslení naměřených výsledků. Naměřená konzumční křivka zobrazená na obr. 4 je tedy věrohodná pouze do okamžiku dosažení hladiny v nádrži na spodní úroveň mostovky. V tomto případě bylo rozhodnuto o využití matematického modelování pro zjištění kapacity bezpečnostního přelivu při velkých povodňových průtocích a maximální kapacity přelivu při dosažení mezní bezpečné hladiny.

\section{MATEMATICKÉ MODELOVÁNÍ}

Matematické modelování bylo použito pro zjištění kapacity bezpečnostního přelivu pro kontrolní povodeň $Q_{10000^{\prime}}$ výsledky fyzikálního modelování posloužily pro kalibraci matematického modelu. $V$ rámci matematického modelování byl použit CFD (Computional Fluid Dynamics) program FLOW-3D v12.0. Program FLOW-3D využívá vyvinuté techniky řešení pohybových rovnic tekutin pro řešení trojrozměrných problémů. Program je možné využít pro řešení širokého rozsahu úloh v oblasti proudění tekutin a šíření tepla, úlohy jsou řešeny metodou konečných objemů za použití RANS (Reynolds Avaraged NavierStokes) rovnic v definované výpočetní oblasti se specifikovanými okrajovými, respektive počátečními podmínkami.

Vlastní model je tvořen výpočetní oblastí, která je tvořena vzájemně spojenými výpočetními buňkami. Buňky rozdělují zájmový prostor na dílči výpočetní objemy. Výpočetní buňky tvoři výpočetní prostor, který efektivně parametrizuje reálný fyzikální prostor. Každý parametr tekutiny je ve výpočetní síti charakterizován řadou hodnot v bodech výpočetní sítě. Skalární veličiny jako např. teplota a tlak jsou definovány ve středu výpočetních buněk, vektorové veličiny jako např. rychlost jsou definovány na stěnách výpočetních buněk. Jelikož se jednotlivé fyzikální parametry v prostoru průběžně mění, jemnější výpočetní sit poskytne presnější popis reality než hrubší výpočetní sít. Jemnější sít ovšem zvyšuje celkové množství výpočetních buněk, a tím zároveň zvyšuje potřebný výpočetní čas. Vytvoření výpočetní mřižky je zásadní krok, který ovlivňuje dobu výpočtu a kvalitu získaných výsledků. Výpočetní sít je tvořena strukturovanou výpočetní sítí (kartézské či cylindrické souřadnice), toto řešení umožňuje stabilní numerické řešení.

Vlastní řešení bylo realizováno na 2D výsekovém modelu, který zahrnoval prostor $v$ nádrži o délce $40 \mathrm{~m}$ a vlastní těleso přelivu s mostovkou. Výpočetní sit byla tvořena buňkami o rozměrech $10 \times 10 \mathrm{~cm}$, v blízkosti přelivu byly buňky zjemněny na $5 \times 5 \mathrm{~cm}$. Citlivostní analýzou byla tato velikost buněk prohlášena za dostatečnou, menší buňky poskytovaly stejné výsledky, ale výpočetní čas byl násobně delší. Horní okrajová podmínka byla nastavena jako hladina v nádrži, dolní okrajová podmínka byla určena jako výtok do volna na konci skluzu bezpečnostního přelivu v dostatečné vzdálenosti tak, aby neovlivnila kapacitu přelivu. Výsledky matematického modelu (obr. 5) korespondovaly s výsledky fyzikálního měření, naměěené hodnoty průtoků se lišily maximálně o $\pm 4 \%$. Ze získané konzumční křivky (obr. 4) je jasně patrné, že VD Vranov dokáže převést kontrolní povodeň cca $1 \mathrm{~m}$ pod mezní bezpečnou hladinou pouze bezpečnostním přelivem, použitím spodních výpustí a vodní elektrárny Ize docílit nižší hladiny.

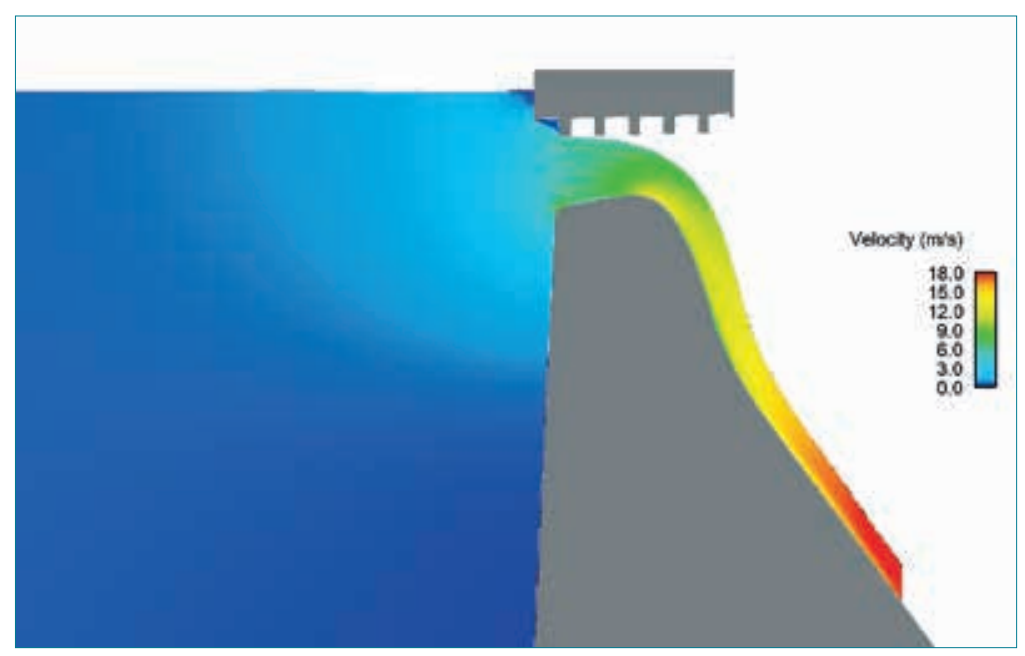

Obr. 5. Rychlostní pole na výsekovém modelu (mezní bezpečná hladina)

Fig. 5. Velocity field - 2D model (maximum water level) 


\section{ZÁVĚR}

Fyzikální výzkum posloužil jako nenahraditelná součást významné rekonstrukce hydrotechnické stavby ve fázi projektové prípravy. Metoda hydraulického modelování v laboratoři je vhodná především pro typy úloh, pro něž není možnost hydraulických výpočtů a matematických modelů na současné úrovni poznání dostatečně spolehlivá. Fyzikální model posloužil zejména př́i posouzení proudových poměrů a tlumení energie výtokového paprsku ve vývaru při provozu spodní výpusti a k přesnému určení kapacity spodní výpusti. Prostorový model hrázového tělesa umožnil komplexně posoudit proudové poměry ve vývaru při převádění povodňových průtoků. Určení kapacity bezpečnostního přelivu proběhlo v těsné spolupráci fyzikálního a matematického modelování, kdy výsledky fyzikálního modelu byly použity pro kalibraci a verifikaci matematického modelu, na kterém byly posléze simulovány stavy, které nebyly technicky snadno proveditelné na fyzikálním modelu.

\section{Literatura}

[1] VÁGNER, J. Manipulační rád pro VD Vranov na řece Dyji v km 175,405. Brno: Povodí Moravy, s. p., vodohospodářský dispečink, 2011.

[2] SEHNAL, J. VD Vranov - rekonstrukce regulačních uzávěrů spodních výpustí: Studie. Brno. Aquatis, 2016.

[3] ŠULC, J. Posouzeni hydraulických poměrů v prostoru spodních výpustí a navazujicího vývaru VD Vranov: rekonstrukce výpustí. Brno: Vysoké učení technické v Brně, Fakulta stavební, Ústav vodních staveb, 2017.

[4] ČÁBELKA, J. a GABRIEL, P. Matematické a fyzikální modelováni v hydrotechnice I - Výzkum na hydraulických modelech a ve skutečnosti. Academia, Praha, 1987.

[5] NOVAK, P., GUINOT, V., REEVE, D., and JEFFREY, A. Hydraulic modelling - an Introduction: Principles, methods and applications. London: Spon Press, 2010. ISBN 978-0-419-25020-3.

\section{Autoři}

\section{Ing. Jan Hlom}

凶jan.hlom@vuv.cz

ORCID: 0000-0002-1365-3604

Ing. Pavel Balvín

凶pavel.balvin@vuv.cz

ORCID: 0000-0001-7892-7584

Výzkumný ústav vodohospodářský T. G. Masaryka, v. v. i.

Příspěvek prošel lektorským řízením.

\section{VRANOV DAM: RESEARCH OF BOTTOM OUTLETS AND CROWN SPILLWAY}

\section{HLOM, J.; BALVIN, P.}

TGM Water Research Institute, p.r.i.

Keywords: bottom outlet - spillway -

physical modeling - mathematical modeling

Waterwork Vranov was completed in 1934, where at that time innovative technology of Johnson-type and cylinder regulating valves was used. During their operation, they did not require major repairs, only routine maintenance and minor repairs was made. However, the current condition of the valves no longer guarantees reliable long-term operation in terms of corrosion and operational damage. Povodí Moravy, s. p., commissioned a study on the reconstruction of regulating valves, the result of which was a proposal to replace four existing valves with four new radial gates. The aim of the research was to verify the functionality of the new designed radial gate valves of the bottom outlets of the Vranov dam and their interaction with the crown spillway and the cascade. As part of the research, two physical models were built - a model of one bottom outlet (scale 1: 14.68) and a model of the dam (scale 1: 55). Within the research on the physical model of the bottom outlet, the main goal was to determine the capacity of the bottom outlet in relation to the water level in the reservoir, the water level of the bottom water and the degree of opening of the radial gate. The model of the dam was used to assess the spatial flow in the stilling basin during the transfer of water through the spillway, or the interaction of stream from the bottom outlets and spillway. Furthermore, the discharge curve of the spillway was verified on the model of the dam body. The measured discharge curve on the physical model was then compared with the discharge curve obtained from the 2D mathematical model. The mathematical model was compiled and calculated in the FLOW-3D.

DOI: 10.46555/VTEI.2020.08.003 